\title{
ANALISIS PERILAKU CAPTIVE AUDIENCE PADA KEGIATAN ENTERTAINMENT BRANDING MELALUI INSERTION SINETRON JODOH WASIAT BAPAK SEBAGAI KEGIATAN KOMUNIKASI PEMASARAN
}

\author{
Indra Novianto Adibayu Pamungkas \\ Prodi Ilmu Komunikasi, Fakultas Komunikasi dan Bisnis, Universitas Telkom ${ }^{1)}$ \\ indra.imi28@gmail.com
}

\begin{abstract}
Abstrak
Persaingan antar brand untuk masuk ke benak manusia bukanlah hal yang mudah. Kebiasaan banyak brand akan mengiklankan produknya namun kenyataan berbanding terbalik, orang tidak suka menonton iklan dan saat ini ada konsep baru dimana iklan dimasukan kedalam alur carita sinetron sebagai branding melalui dunia hiburan atau Entertainment Branding. Kondisi ini membuat pesan iklan diterima oleh audience captive. Penelitian ini bertujuan untuk melihat proses captive audience ketika menonton insertion iklan pada sinetron Jodoh Wasiat Bapak hingga mencapai enggagemet. Penelitian ini menggunakan penelitian kualitatif yang diambil dari proses wawancara mendalam. Dari penelitian ini didapati Captive audience dapat menjadi potential consumer untuk suatu brand hingga melakuakn enggageent. Pada dasarnya captive audience tidak sadar mereka sedang diinfomasikan suatu produk karena tujuan utama mereka adalah menonton sinteronnya. Dalam penelitian ini, captive audience dapat melakukan engagement produk dan mengingat bahwa ia diperkenalkan dari insertion pada sinetron tersebut.

Kata kunci : Insertion, Entertainment Branding, Captive Audience

\section{PENDAHULUAN}

Persaingan antar brand semakin kompleks dan membutuhkan banyak cara untuk membuat suatu brand untuk berhasil menempati otak manusia. Manusia hidup tidak bisa lepas dari brand mulai ia bangun tidur hingga kembali tidur. Proses penerimaan pesan oleh seseorang biasanya dari kegiatan promosi. Kegiatan promosi tersebut salah satunya adalah iklan. Pada dasarnya orang tidak begitu menyukai menonton iklan dan hal yang dilakukan adalah melakukan perpindahan channel ketika sedang menonton televisi. Hal ini membuat pelaku pemasaran harus berpikir ulang bagaimana membuat suatu perubahan dalam penyampaian pesan iklan.

Digitalisasi membuat banyak orang mulai berubah dari cara menikmati media. Dilansir dari Republika.co.id yang mengangkat penelitian dari Nielsen Consumer Media View 2017 menujukan adalahnya peningkatan minat dalam menonton secara online dan hal ini membuat penggunanya juga bergeser. Namun disisi lain ternyata konsumen tetap tidak bisa meninggalkan media visual lama yaitu televisi. Selebihnya, Hal ini juga termasuk adanya pergeseran perilaku penonton yang sekaligus pemiliki perangkat mobile dimana mereka menonton televisi dengan menggunakan internet dalam waktu bersamaan atau lebih dikenal dengan dual screen. Hasil penelitian Nielsen Consumer Media View yang melibatkan lebih dari 17.000 orang berusia di atas 10 tahun pada lebih dari 11 kota besar Indonesia ini menyebutkan bahwasannya peminat televisi masih berada pada $96 \%$, media luar ruang $53 \%$ dan internet
\end{abstract}


44\% sehingga membuktikan bahwasannya penetrasi televisi masih memimpin. ( Sumber: Trendtek. Republika.co.id)

Televisi merupakan sarana seseorang untuk memenuhi kebututuhan akan hiburan dengan tanpa mengeluarkan biaya tambahan lagi dan perilaku menonton tv bisa jadi menyita waktu. Diansir dari Tabloid Bintang.co.id, Head of Dept Channel and Licence PT. Surya Citra Media (SCM) , Chairunisa Munni melihat bahwa program sinetron dan FTV merupakan jenis program yang masih diminati masyarakat Indonesia.Salah satunya dipengaruhi kalangan penonton yang masih banyak terdiri dari ibu rumah tangga dan anak-anak muda yang memang menyukai jenis program seperti ini."Kebanyakan penonton Indonesia mungkin senangnya drama, yang sedih-sedih, yang kisahnya menyayat hati," ungkapnya saat diskusi panel Evolusi TV bersama Mivo di Hyde, Kemang, Jakarta Selatan. "Orang akan lebih memilih program menghibur, ringan dan tidak ada unsur politik karena terlalu capek. Jadi, mencari program yang bisa lebih memotivasi, happy dan lebih bersemangat," lanjut Munni. Tambah lagi, dia percaya program yang ringan, memotivasi dengan nilai-nilai positif menjadi bentuk program yang diperlukan masyarakat Indonesia.

Ukuran keberahasilan dari sebuah tanyangan adalah rating dan share. Dilansir dari pictame.com berikut adalah rating acara tv di Indonesia adalah sebagai berikut :

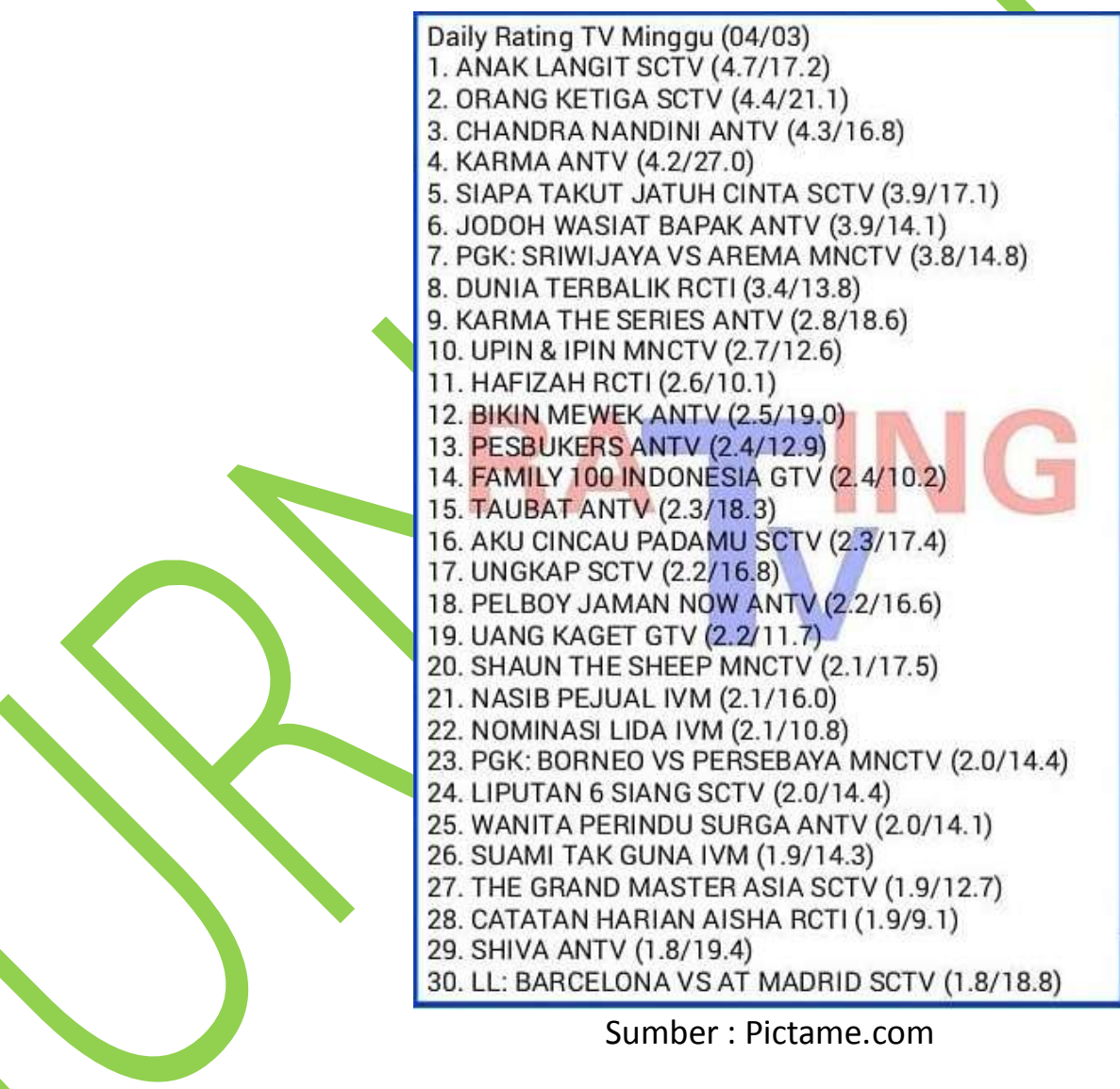

Dari data diatas terlihat bahwa sinetron dengan posisi pertama ada pada stasiun SCTV namun peneliti meninjau dari sisi share. Rating jumlah penonton suatu siaran atau program di bagi populasi televisi. Kalau share adalah jumlah penonton suatu program dibagi jumlah orang yang pada saat itu sedang menonton TV dengan kata lain, secara perhitungan, Rating adalah perhitungan dari semua pemilik TV sedangkan share adalah perhitungan dari orang yang menonton tv atau dihitung dari yang menyala saja maka dilansir dari pictame.com bahwa televisi dengan share terbesar sampai dengan jumat 2 maret 2018 adalah sebagai berikut: 


\section{RATING}

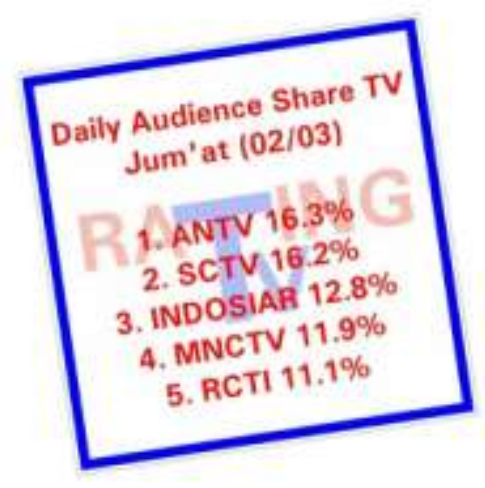

Sumber: Pictime.com

Bedasarkan data diatas, maka ANTV menduduki urutan pertama dalam hal share. Untuk itu peneliti akan fokus pada acara di ANTV. Melihat dari data rating diatas maka acara di stasiun ANTV yang menjadi rating adalah sebagai berikut

\begin{tabular}{|r|l|c|c|}
\hline $\begin{array}{c}\text { PERINGKAT } \\
\text { RATING }\end{array}$ & RATING & SHARE \\
\hline 1 & KARMA ANTV & 27.0 & 4.2 \\
\hline 2. & JODOH WASIAT BAPAK & 14.1 & 3.9 \\
\hline 3 & KARMA THE SERIES & 18.6 & 2.8 \\
\hline 4. & BIKIN MEWEK & 19.0 & 2.5 \\
\hline 5. & PESBUKER & 12.9 & 2.5 \\
\hline 6. & TAUBAT ANTV & 18.3 & 2.3 \\
\hline 7. & PELBOY JAMAN NOW & 16.6 & 2.2. \\
\hline 8. & WANITA PERINDU SURGA & 14.1 & 2.0 \\
\hline 9. & SHIVA ANTV & 19.4 & 1.8 \\
\hline
\end{tabular}

Sumber olahan peneliti 2018

Blla melihat share, posisi pertama acara di ANTV adalah KARMA ANTV dimana bentuk dari acara tersebut adalah reatity show, namun dalam penelitian ini, peneliti akan meneliti tentang insertion iklan sebagai Brand entertaining. Dari program ANTV diatas sinetron JODOH WASIAT BAPAK adalah bentuk sinetron dimana didalam acaranya terkandung insertion brand melalui jalan cerita nya. Salah satu kegiatan dari branding entertainment adalah Branding melalui program televisi (Marc Lehu, 2009). Tambah lagi , Jodoh wasiat bapak tayang pada waktu prime time dimana sebuah berita tahun 2015 mengungkapkan program Serial ditayangkan pada waktu prime time yang memiliki potensi jumlah penonton tertinggi, yaitu pada pukul 18.00 - 21.59 WIB. Hal inilah yang membuat program Serial masih meraih poin rating yang tinggi (sumber: beritasatu.com)

Jodoh Wasiat Bapak adalah sinetron dengan memiliki penggabungan genre yaitu mistis, religi dan romantis. Dalam setiap episodenya bercerita mengenai penggabungan genre tersebut, unsur Religi lebih mengajarkan tentang arti pasrah dan selalu bertawakal pada Allah SWT dan bagaimana kita selalu perduli dan melakukan pekerjaan mulia seperti pengantar jenazah, Unsur mistis diambil dari jalan ceritanya terkait keserakahan dan sampai membuat orang tewas sehingga ada arwah bergentayangan dan bila digabungkan dengan inti pekerjaan pemeran utamanya, maka jenazah yang menjadi korban akan dimakamkan secara 
layak. Sinetron ini juga memberi sentuhan unsur romantisme dimana sosok Adam yang diperankan oleh Aldy Fairus yang juga seorang pengantar jenazah yang mengalami problematika dengan kekasihnya Kania yang diperankan oleh pendatang baru Imas Fitria. Namun ketersinambungan dari cerita ini adalah kedua pasang kekasih ini juga saling membantu dalam hal mengurus jenazah.

Dalam sinetron ini, tak sedikit brand-brand yang melakukan insert pada sinetron ini. Iklan bukan dihadirkan secara terpisah, namun iklan masuk kedalam jalan cerita dimana hal ini membuat audience menjadi captive (Marc Lehu, 2009) atau seseorang tidak sadar ketika sedang diinformasikan

Bila melihat profil penonton televisi di Indonesia, bedasarkan hasil wawancara dengan komunitas Jaringan siaran, Bayu Wardhana yang dilansir dari merdeka.com mengatakan bahwa SES B dan C, menengah kebawah adalah penonton televisi Indonesia dengan menonton drama rumah tangga. Tidak ada pilihan bagi kelompok $C$ karena tidak ada pilihan lain namun kelas A kini mulai berlangganan TV kabel karena ada edukasinya dan tidak terbatas hiburan namun TV swasta kurang menaruh dimensi. (Sumber: merdeka.com) .

Menurut data tahun 2011 yang dilansir dari Lembaga Riset Nielsen mencatat penambahan jumlah penonton sinetron hingga $51 \%$ dari 969 ribu orang pada kuartal pertama 2010 menjadi 1,4 juta orang pada periode 2011. Menurut Manager media client service Andini Wendjaru di Jakarta, Sebagian besar penonton sinetron adalah perempuan berusia 30 tahun dari kelas mengengah kebawah. Nielsen juga mencatat permirsa dari kota Banjarmasin, Bandung dan Makassar sebagai pemirsa yang paling sertia menonton sinetron ( Sumber: Antaranews.com)

Bedasarkan latar belakang tersebut, peneliti ingin menganalisi tentang insertion iklan pada sinetron Jodoh Wasiat Bapak sebagai suatu kegiatan brand entertainment dimana ini merupakan kegiatan komunikasi pemasaran . penelitian ini ditujukan pada captive audience dari kalangan perempuan denganusia 30 tahun keatas dengan social economy status menengah kebawah dimana mereka adalah penonton setia sinetron. Penelitian ini dilakukan di kota Banjarmasin, Bandung dan Makassar dimana ketiga tempat ini adalah pemirsa paling setia yang menonton sinetron.

\section{TINJAUAN PUSTAKA}

Dalam penelitian ini, peneliti menggunakan berbagai tinjauan pustaka yang mendukung agar penelitian ini terarah. Adapun tinjauan pustaka tersebut adalah sebagai berikut:

\section{Komunikasi Pemasaran}

Komunikasi merupakan salah satu aspek penting yang dapat menentukan kesuksesan kegiatan pemasaran. Konsep dasar komunikasi yang diaplikasikan kedalam pemasaran adalah sebagai fondasi dalam proses penyampaian pesan atau informasi kepada konsumen. Tujuan terpenting komunikasi dalam kegiatan pemasaran adalah untuk mengubah perilaku para pemegang kepentingan atau konsumen (Hermawan, 2012:51)

Komunikasi pemasaran didefinisikan oleh Keegan dkk, 1995 dalam (Machfoedz, 2010 :16) sebagai "semua elemen dalam pemasaran yang memberi arti dan mengkomunikasikan nilai kepada konsumen dan stakeholder sebuah perusahaan". Komunikasi Pemasaran ialah istilah yang mengacu kepada menerangkan informasi terkait produk atau jasa yang ditawarkan oleh pemasar kepada konsumen. Pemasar dapat memanfaatkan beberapa cara atau media dalam menyebarkan informasi, seperti melalui iklan, pemasaran langsung, publisitas, promosi penjualan, bahkan penjualan langsung demi mempengaruhi keputusan pembelian konsumen. Sementara sebaliknya, konsumen menggunakan media-media tersebut untuk mendapatkan informasi ataupun pengetahuan tentang produk (Machfoedz, 2010:17).

Model komunikasi konvensional, merupakan dasar dari komunikasi pemasaran. Intinya didalam proses komunikasi pemasaran, informasi diharapkan dapat diterima dan mempengaruhi sikap penerima alias konsumen potensial untuk melakukan pembelian. 
Ilmu pemasaran secara umum, dan komunikasi pemasaran secara khusus berkembang dari persepsi pentingnya pertumbuhan ekonomi. Umumnya, komunikasi pemasaran atau promosi dilihat dan terus-menerus dilihat sebagai empat aspek yang paling yang paling menonjol, atau biasa disebut sebagai Marketing Mix (de Pelsmacker dkk, 2007) dalam (Egan, 2015:11). Dalam kasus ini, promosi dilihat sebagai sesuatu yang dapat dikombinasikan dengan tiga elemen lainnya (product, place, and price) dalam membuat profil marketing yang unik untuk produk atau brand tertentu. Kegunaan dari kombinasi elemen-elemen tersebut ialah untuk memfasilitasi pertukaran dengan konsumen pada marketplace (Belch \& Belch, 2011). 4Ps of marketing model atau (produk, place, price and promotion) dikembangkan oleh (McCarthy, 1960), yang merupakan penyuntingan dari "twelve elements of a marketing programme" yang diciptakan oleh Borden, dimana beberapa diantaranya dikenal sebagai tools komunikasi pemasaran.

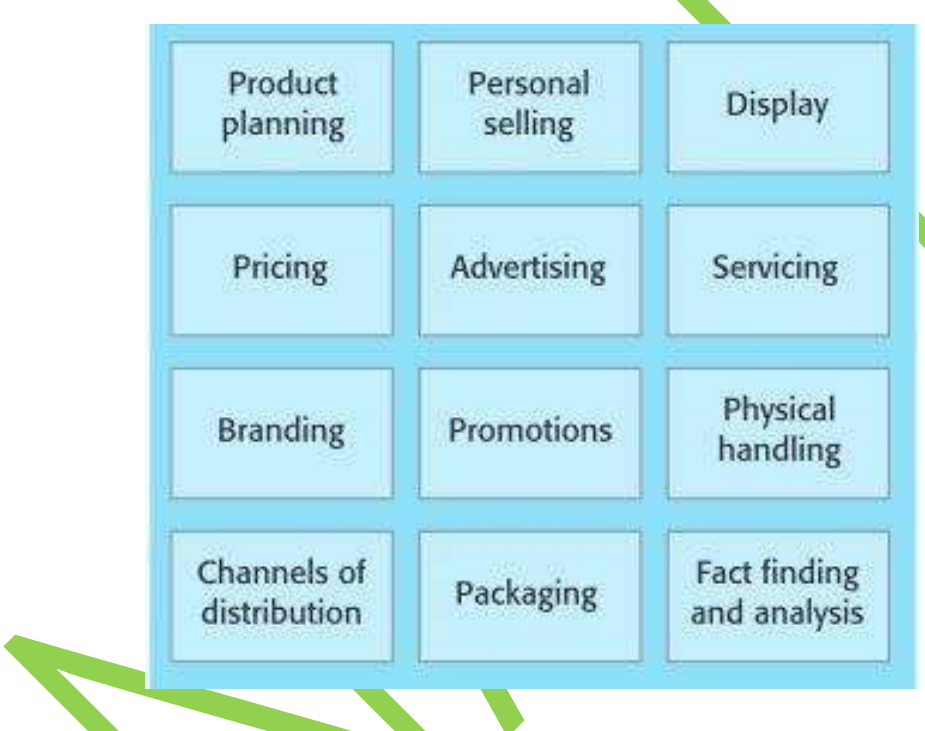

Gambar 1. BORDEN'S ELEMENTS OF A MARKETING PROGRAMME

Sumber : (Egan, 2011: 23)

Prinsip Dasar Komunikasi Pemasaran

Kegiatan komunikasi yang ditujukan untuk menyampaikan pesan kepada konsumen dan pelanggan dengan menggunakan media dan saluran yang dipergunakan dengan harapan terjadi tiga perubahan. Seperti yang dijelaskan dalam buku Marketing in Cyber Media (Soemanegara,2008 dalam pamungkas dan Lestari, 2016) menyebutkan 3 perubahan tersebut adalah:

1. Sharing Knowledge

2. Changing Attitude

3. Getting new behavior 
Bila diterjemahkan pada sebuah gambar maka tujuan komunikasi pemasaran adalah sebagai berikut:

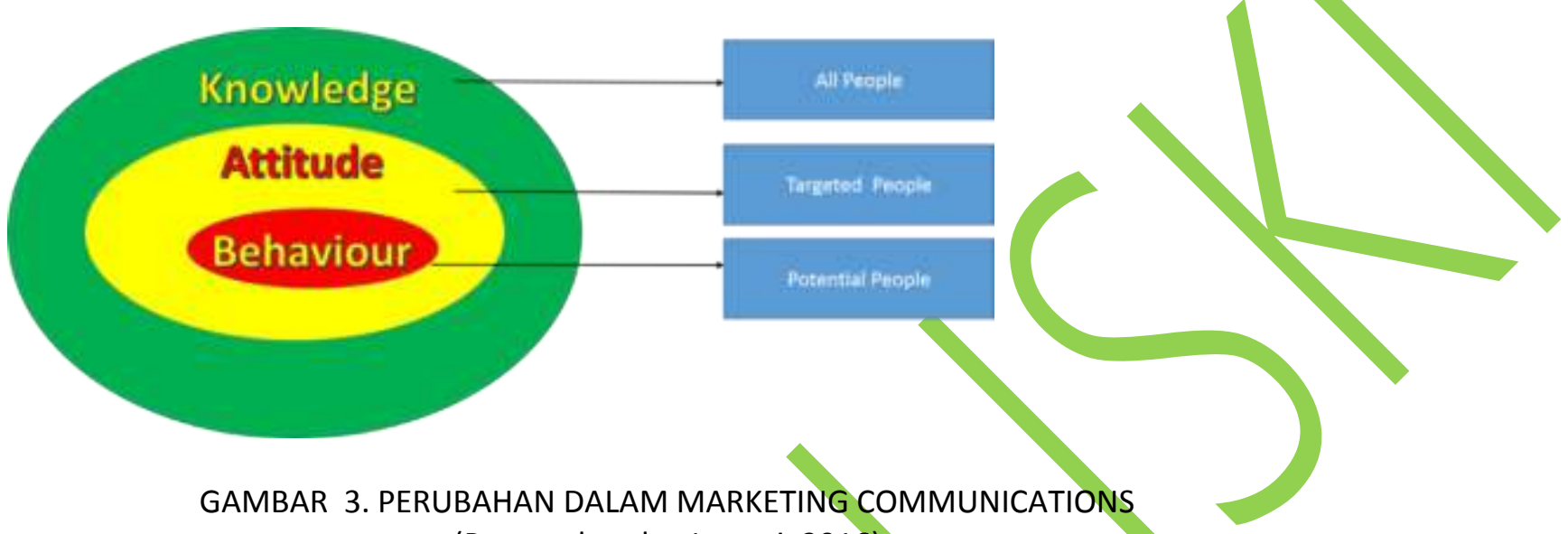

(Pamungkas dan Lestari, 2016)

Mari kita jelaskan satu persatu mengenai gambar diatas:

1. Sharing Knowledge

"komunikasikan brand atau produk anda kepada siapa saja" kalau bisa semua orang tahu produk anda. Ini adalah proses memberikan cognitive bagi konsumen. Nantinya konsumen akan menyadari atau tidak tentang suatu produk atau brand. Sejujurnya bila mengkomunikasikan brand, maka tidak ada batasan orang untuk tidak boleh tau tentang keberadaan brand kita. Komunikasikan saja brand seluas mungkin namun tata cara atau pesannya disesuaikan dengan market yang kita bidik. Bila ingin dijabarkan bahwa banyak kriteria audience ketika proses terpaaan komunikasi terjadi diantaranya:

a) Audience yang tidak terlibat sama sekali

Audience pada kategori ini biasanya mengatakan

"I don't know the product so I don't Respond it"

Pada kategori ini, audience bisa jadi tidak tertempa sama sekali apa yang dikomunikasikan oleh terterpa perusahaan sehingga mereka tidak tau apa yang dikomunikasikan oleh sebuah brand

Misalnya:

Rata-rata anak berpendidikan SD tidak bisa jadi tahu keberadaan suatu merek rokok, dikarenakan pengkomunikasian produk dilakukan pada jam malam hari disaat mereka tidur. 
b) Audience dengan sedikit keterlibatan

Konsumen pada kategori ini biasanya mengatakan

"I know the product so I don't too much Respond it"

Pada kategori ini, konsumen terterpa melalui proses komunikasi, Sehinnga mereka tahu keberadaan suatu merek atau produk namun mereka bisa jadi kurang perduli dengan keberadaan merek tersebut dikarenakan sudah setia dengan produk atau brand sejenis yang sedang digunakannya. Dengan kata lain keterlibatan konsumen jenis ini adalah sebatas mengetahui keberadan suatu merek saja.

Misalnya: Saya tahu ada detegen merek $X$ tapi saya sih sudah pakai merek $Y$

c) Audience dengan banyak keterlibatan

Pada kateogori ini biasanya jenis konsumen yang mengatakan "I know the product and I'll Respond it

Konsumen pada kategori ini dapat menerima apa yang dikomunikasikan melalui terpaan dan mereka memberikan respon terhadap produk. Bisa jadi mereka mau mencoba sampai membeli sebuah produk.

Misalnya: "Saya tau ada produk pengusir tikus dengan gelombang elektro magnetic, saya mau coba untuk menggunakannya sekarang"

d) Konsumen dengan menunda keterlibatan

Pada kateogori ini biasanya jenis konsumen yang mengatakan "I know the product and may be I Respond it someday"

Pada kategori ini konsumen mengetahui tentang keberadaan suatu merek atau produk namun tidak merespon untuk saat ini. Secara tidak sadar, mereka telah merekam dalam memori keberadaan suatu produk atau merek dalam memori mereka. Sehingga suatu saat dibutuhkan maka otak mereka akan memanggil kembali nama brand nya.

Misalnya: seorang ibu bisa memakai bumbu penyedap rasa merek " $X$ " suatu hari dia pergi ke warung dan ternyata bumbu penyedap rasa merek " $x$ "tidak ada maka bisa jadi dia ingat ada alternative lain yaitu bumbu penyedap rasa merek " $\mathrm{Z}$ "

2. Changing Attitude

Dari semua orang yang diterpa oleh stategi komunikasi pemasaran yang kita rancang, maka kita kita harus ingat prinsip "Kita tidak bisa membahagiakan semua orang" namun bukan berarti "kita tidak bisa mengkomunikasikan kepada semua orang". Diantara mereka yang diterpa oleh pesan komunikasi, ada tentunya yang merubah sikapnya. Biasanya mereka adalah orang -orang yang ditargetkan oleh perusahan. Adapun perubahan-perubahan sikap yang biasanya muncul adalah:

1. Dari yang tidak tahu menjadi tahu

2. Dari tidak peduli menjadi perduli

3. Dari negative menjadi positive

4. Dari yang apatis menjadi simpati

Dan masih banyak lagi sikap sikap yang akan muncul. Tentunya dari empat contoh sikap diatas merupakan sesuatu yang diharapkan oleh perusahaan.

3. Getting new Behavior

Kembali lagi diingatkan bahwa kita tidak bisa membahagiakan semua orang bukan berarti kita tidak bisa mengkomunikasikan kepada orang. Artinya dari semua sikap yang terbangun di atas bukan berati mereka semua akan melakukan tindakan lebih lanjut kepada produk atau brand kita. Mereka yang sebagai target market 
potensial pun akan terseleksi alam kembali untuk dapat membeli, mencoba, bahkan merekomendasikan produk atau brand kita mengingat adanya pesaing sejenis.

\section{Entertainment Branding}

Melakukan branding melalui industry hiburan dapat membantu dalam memperkuat citra sebuah brand. Dalam hal penyampaian konten pun menjadi simbiosis mutualisme dikarenakan baik secara konten dan kebutuhan penonton sama-sama saling bisa menerima tanpa adanya rasa keterpaksaan. Hal ini menjadi alasan bagus terutama bagi marcommers untuk mendapatkan perhatian dari audience agar memiliki keterlibatan emosional atas suatu keterlibatan brand.

(Lehu, 2009) menjelaskan ada berbagai macam bentuk dari Branding Entertainment di antaranya adalah:

1) Branding pada program televisi

Program serial televisi kini lebih dimintai oleh pengiklan karena dapat menarik perhatian audience lebih besar dari pada jeda komersial. Ini membantu konsumen mengingat nama program sekaligus nama brand nya. Cara penyampaian konten-nya ibarat menenun alur cerita. Biasanya dikaitkan dengan reality show, cerita dalam novel, lagu atau film.

2) Insertion pada Film, TV program atau Cinema

Memasukan produk atau brand kedalam sebuah program TV atau film akan memiliki keuntungan dari segi waktu dan perhatian. Ini menjadi kelebihan tersediri dibandingkan beriklan secara spot. Penonton mempunyai peluang untuk menjadi captive audience di mana mereka seolah dipakasa melihat sebuah brand karena merupakan bagian dari isi cerita.

3) Lirik lagu

Saat ini penempatan dalam lagu dapat menjadi sarana yang sangat baik untuk mencapai sasaran tertentu.

4) Games Ads

Sama halnya dengan placemen di film, melakukan branding melalui permainan games juga dapat menarik perhatian audiencenya. Kelebihannya justru audience ikut terlibat dalam permainannya. Games advertising bisa menjadi effective ketika target audience-nya adalah pengguna games atau gammers namun ini bisa menjadi peluang bagus untuk target anak remaja menuju dewasa. Bahkan 40\%-nya sudah menjangkau kaum perempuan.

Iklan

Pengertian Iklan

Iklan adalah segala bentuk presentasi non-pribadi dan promosi gagasan, barang atau jasa oleh sponsor tertentu yang harus dibayar (Kotler, 2005:277).

Menurut Fandi Tjiptono (2008:225) menyatakan bahwa iklan merupakan salah satu bentuk promosi yang paling banyak digunakan perusahaan dalam mempromosikan produknya.

Selain itu, menurut Machfoedz (2010:139) bahwa iklan adalah segala bentuk penyajian informasi dan promosi secara tidak langsung yang dilakukan oleh sponsor untuk menawarkan ide, barang atau jasa.

\section{Tujuan beriklan}

Adapun tujuan beriklan ada (pamungkas, 2017) adalah sebagai berikut:

1) Recruit New Customer

Iklan dapat memberikan informasi untuk membangun awareness tentang sebuah brand sehingga memungkinkan orang baru menyadari keberadaan produk atau jasa dari sebuah brand sehingga akan memiliki peluang untuk melakukan engagement. 
2) Retain Loyal Customer

Jangan lupakan konsumen lama anda, ibaratnya konsumen setia ini adalah mereka yâng juga mempunyai peluang untuk berbicara mengenai produk dan jasa dari brand anda. Mereka harus selalu diingatkan bahwa brand anda itu masih eksis dan ada bersama mereka.

3) Retrieve Lost Customer

Konsumen yang telah pergi bukan berarti tidak bisa dibuat untuk kembali. Pada prakteknya ini memang sulit melakukannya. Dengan menginformasikan value yang baru dari produk atau jasa layanan anda, bisa menjadi peluang mereka untuk berdekatan kembali dengan brand anda.

Tujuan Komunikasi dalam Periklanan

Tujuan komunikasi dalam periklanan atau kita bisa menyebutnya dengan Advertising Communication Objective (Shimp, 2000) Diantaranya:

1) Informing (memberi informasi)

Tujuan komunikasi ini merupakan tujuan penyampaian pesan tentang suatu produk baru. Periklanan dibuat untuk menyadarkan konsumen (aware) akan keberadaan merek-merek baru. Memberi informasi disini juga bisa sekaligus mendidik mereka tentang berbagai fitur dan manfaat merek Memfasilitasi penciptaan citra merek yang positif. Dengan kata lain, Informing juga berarti memfasilitasi pengenalan (introduction) merek-merek baru Meningkatkan puncak kesadaran dalam benak konsumen (TOMA - top of mind awareness) untuk merek-merek yang sudah ada dalam kategori produk yang matang.

2) Persuading (mempersuasi)

Iklan yang efektif akan mampu mempersuasi pelanggan untuk mencoba produk dan jasa yang diiklankan. Dalam hal ini mempersuasi lebih utama dari pesan periklanannya didukung dengan artistic baik secara audio, visual dan audio visual.

3) Reminding (mengingatkan)

Iklan dibuat untuk menjaga agar merek perusahaan tetap segar dalam ingatan konsumen. Ini biasanya dilakukan oleh brand-brand yang sudah lama eksis. Hal ini dilakukan sebagai upaya mengingatkan audience bahwa brand mereka masih eksis ditengah persaingan yang semakin kompleks.

4) Adding Value

Memberikan nilai tambah, iklan harus bisa memberikan nilai tambah produk dan mempengaruhi persepsi konsumen (positif).

5) Assiting

Mendampingi, salah satu fungsi utama dari iklan adalah mendampingi atau manfasilitasi upaya-upaya perusahaan lainnya.

\section{Captive Audience}

Bedasarkan kamus dari Cambridge.org Captive audience didefinisikan sebagai " a group of people who listen or watch someone or something because they cannot leave" ( sekumpulan orang yang mendengarkan atau menonton seseorang atau sesuatu karena mereka tidak dapat meninggalkannya)

Bila dihubungan dengan penempatan produk memiliki masa depan yang cerah karena periklanan tradisional - terlihat invasif, membosankan dan tidak bersemangat - semakin terdevaluasi. Konsumen mengharapkan sesuatu yang baru dari iklan terkait dengan produk yang dipromosikannya, dan wacana periklanan itu sendiri. Inilah kekuatan penempatan produk, yang menawarkan alternatif komunikasi non-agresif, terkait dengan dunia yang percaya dan dengan bintang film. Efektivitas tempat iklan televisi yang semakin mahal 
ditantang untuk mendukung hubungan masyarakat dan operasi pemasaran langsung (contoh, promosi dasi, kompetisi dan sebagainya). Dengan cara ini, bioskop adalah media masa depan: merek terlibat dalam konteks yang terputus dari dunia periklanan, dan ditujukan kepada pemirsa yang captive dan positif. (Lehu, 2009)

\section{METODE PENELITAN}

Paradigma yang digunakan peneliti adalah post-positivisme. Paradigma postpositivisme berpendapat bahwa peneliti tidak mampu mendapatkan fakta dari suatu kenyataan apabila peneliti membuat jarak (distance) dengan kenyataan yang ada. Hubungan peneliti dengan realitas harus bersifat interaktif. Oleh karena itu digunakan prinsip trianggulasi, yaitu penggunaan bermacam - macam metode, sumber data, dan data. (Tahir, 2011: 57-58).

Teknik pengumpulan data didalam penelitian kualitatif berbeda dengan penelitian kuantitatif. Dimana didalam penelitian kualitatif peneliti merupakan instrumen utama untuk mencari data dengan melakukan interaksi secara simbolik dengan informan/subjek yang diteliti. Metode pengumpulan data seperti yang dijelaskan oleh Kriyantono (2014:95) adalah teknik atau cara-cara yang dapat digunakan periset untuk mengumpulkan data. Dalam riset kualitatif dikenal metode pengumpulan data: observasi (field observations), focus group discussion (FGD), dan wawancara mendalam (depth interview). Dalam penelitian ini penulis melakukan pengumpulan data dengan menggunakan metode Wawancara adalah suatu percakapan yang diarahkan pada suatu masalah tertentu, ini merupakan proses tanya jawab lisan, dimana dua orang atau lebih berhadap-hadapan secara fisik (Kartono, dalam Gunawan 2013:160). Dalam penelitian ini penulis melakukan wawancara ke beberapa informan yang terkait dengan permasalahan penelitian ini.

Bila dilihat dari sumber datanya, maka pengumpulan data dapat menggunakan sumber primer dan sumber sekunder. Menurut (Satori dan Komariah, 2012:103) sumber primer adalah sumber data yang langsung memberikan data kepada peneliti, dan sumber sekunder merupakan sumber yang tidak langsung memberikan data kepada peneliti. Berdasarkan sumber data di atas maka penulis mengklasifikasikan sumber-sumber data ke dalam jenis-jenis data, yaitu:

1. Data Primer

Data primer adalah data yang diperoleh langsung dari sumbernya, diamati, dicatat, untuk pertama kali. Data ini berasal dari informan kunci. Moleong (2006: 157) mengemukakan data primer adalah kata-kata dan tindakan orangorang yang telah diamati dan dilakukan wawancara melalui catatan tertulis, melalui rekaman video, audio tape, dan pengambilan foto.

2. Data Sekunder

Data sekunder merupakan sumber yang tidak langsung memberikan data kepada pengumpul data, misalnya melalui orang lain atau dokumen-dokumen yang ada (Satori dan Komariah, 2012:103) peneliti mendapatkan informasi sebagai data sekunder melalui beberapa cara, yaitu:

Studi pustaka

Peneliti mencari referensi acuan untuk mendukung penelitian ini melalui studi pustaka melalui buku teks, jurnal, materi belajar yang didapatkan di kelas, makalah penelitian untuk memperoleh teori dan membandingkan dengan kenyataan di lapangan, sehingga dapat melengkapi isi penelitian ini. 
Data Perusahaan

Jika perusahaan memberikan data perusahaan untuk melengkapi data atau informasi terkait penelitian ini akan lebih mudah bagi peneliti menganalisa dan mengolah data untuk memperoleh hasil penelitian yang valid.

1. Internet

Sebagai tambahan, peneliti menggunakan informasi dari media sosial objek penelitian, dan info berita tentang perusahaan guna mencari informasi. Selain itu, website lainnya juga digunakan dalam mencari pengertian dari istilah-istilah yang sulit dipahami.

Menurut Sugiyono (2013: 243), dalam penelitian kualitatif, data diperoleh dari berbagai sumber dengan menggunakan teknik pengumpulan data yang beragam, dan dilakukan secara terus-menerus sampai datanya jenuh atau kaya akan data. Dengan pengamatan yang terus menerus tersebut mengakibatkan variasi data tinggi sekali. Gunawan (2013: 209) menyatakan bahhwa analisis data merupakan bagian yang sangat penting dalam penelitian karena dari analisis ini akan diperoleh temuan, baik temuan substantive maupun formal. Miles dan Huberman (Sugiyono, 2013: 246) mengemukakan bahwa aktivitas analisis data kualitatif dilakukan secara interaktif dan berlangsung secara terus menerus sampai tuntas, sehingga datanya sudah jenuh. Aktivitas dalam analisis data, yaitu data reduction (reduksi data), data display (penyajian data), dan conclusion drawing/verification (penarikan kesimpulan dan verifikasi).

1. Data reduction (Reduksi data)

Mereduksi data berarti merangkum, memilih hal-hal yang pokok, memfokuskan pada hal-hal yang penting, dicari tema dan polanya. Dengan demikian, data yang telah direduksi akan memberikan gambaran yang lebih jelas, dan mempermudah peneliti untuk melakukan pengumpulan data selanjutnya, dan mencarinya bila diperlukan. Dalam mereduksi data, peneliti akan dipandu oleh tujuan yang akan dicapai yaitu temuan (Sugiyono, 2013: 247).

2. Data display (Penyajian data)

Setelah dilakukan reduksi data, maka langkah selanjutnya adalah penyajian data. Dalam penelitian kualitatif, penyajian data bisa dilakukan dalam bentuk uraian singkat, bagan, hubungan antar kategori, flowchart dan sejenisnya. Dalam hal ini Miles dan huberman (Sugiyono, 2013: 249) menyatakan bahwa yang paling sering digunakan untuk menyajikan data dalam penelitian kualitatif adalah teks yang bersifat naratif.

3. Conclusion drawing/Verification (Penarikan kesimpulan dan verifikasi)

Langkah ketiga dalam analisis data kualitatif menurut Miles dan Huberman (Sugiyono, 2013: 252) adalah penarikan kesimpulan dan verifikasi. Kesimpulan dalam penelitian kualitatif mungkin dapat menjawab rumusan masalah yang dirumuskan sejak awal, tetapi mungkin juga tidak, karena masalah dan rumusan masalah dalam penelitian kualitatif masih bersifat sementara dan akan berkembang setelah peneliti berada di lapangan.

Teknik keabsahan data yang digunakan pada penelitian ini adalah teknik triangulasi data. Dengan menggunakan teknik ini, maka dapat mengarahkan penulis untuk menggunakan berbagai sumber data yang tersedia dalam mengumpulkan data dan informasi penelitian. Selanjutnya Sugiyono (2009: 127-129) membagi triangulasi menjadi tiga jenis, yaitu:

a. Triangulasi Sumber, yakni membandingkan dan mengecek balik informasi atau data yang diperoleh dari sumber yang berbeda.

b. Triangulasi Metode atau Teknik, yakni membandingkan dan mengecek balik informasi atau data yang diperoleh dari pengumpulan data yang berbeda-beda. 
c. Triangulasi Waktu, yakni melakukan pengecekan data dengan waktu yang berbeda. Pengamatan tidak hanya dilakukan satu kali, tetapi beberapa kali dalam waktu yang berbeda.

\section{HASIL DAN PEMBAHASAN}

Penelitian ini merupakan penelitian kualitatif dimana peneliti melakukan wawancara mendalam kepada 6 (enam) orang wanita berusia 30 tahun lebih, berada pada social economic status B dimana ke enam informan ini adalah profil penonton sinetron di Indonesia. Peneliti melakukan wawancara dengan informan yag tinggal di Banjarmasin, Bandung dan Makassar dimana ketiga kota ini adalah kota dengan penonton sinetron paling banyak.

Peneliti bertanya kepada ke enam informan mengenai kesadaran mereka akan iklan yang menjadi bagian dari alur cerita dalam sinetron Jodoh Wasiat Bapak, didapati jawaban dengan alasan sebagai berikut:

\begin{tabular}{|l|l|l|l|}
\hline Informan & Asal & Jawaban & Alasan \\
\hline I & Banjarmasin & $\begin{array}{l}\text { Tidak } \\
\text { sadar }\end{array}$ & Sudah Masuk alur cerita \\
\hline II & Bandung & $\begin{array}{l}\text { Tidak } \\
\text { sadar }\end{array}$ & Sudah Masuk alur cerita \\
\hline III & Bandung & $\begin{array}{l}\text { Tidak } \\
\text { sadar }\end{array}$ & Sudah Masuk alur cerita \\
\hline IV & Makassar & $\begin{array}{l}\text { Tidak } \\
\text { sadar }\end{array}$ & Sudah Masuk alur cerita \\
\hline V & Banjarmasin & $\begin{array}{l}\text { Tidak } \\
\text { sadar }\end{array}$ & Sudah Masuk alur cerita \\
\hline VI & Makassar & $\begin{array}{l}\text { Tidak } \\
\text { sadar }\end{array}$ & Sudah Masuk alur cerita \\
\hline
\end{tabular}

Keenam infoman tidak menyadari adanya iklan dikarenakan mereka mengira bahwa iklan tersebut adalah bagian dari alur cerita. Peneliti melakukan observasi pada sinetron Jodoh Wasiat Bapak, bahwa alur cerita dibuat seolah sama dengan adegan -adegan lainnya, mulai dari masuknya masik hingga jalan cerita. Namun hal ini tidak disadari oleh keenam informan namun peneliti bertanya pada keenam informan dan didapati jawaban bahwa mereka menyadari ada produk yang menjadi bagian dari alur cerita. Keenam informan sama sekali tidak merasa harus memindahkan channel dikarenakan mereka tidak sedang menonton iklan melainkan bagian dari cerita. Namun peneliti bertanya apakah mereka menonton atau memindahkan channel pada saat bagian kuiz suatu brand $X$ bersama Jodoh Wasiat Bapak didapati jawaban sebagai berikut:

\begin{tabular}{|l|l|l|l|}
\hline Informan & Asal & Jawaban & Alasan \\
\hline I & Banjarmasin & Tidak & Nagapain nonton quis, pindah aja \\
\hline II & Bandung & Ya & $\begin{array}{l}\text { Kadang Males pindah-pindah lagi takut } \\
\text { ketinggalan saya biarkan saja tv nyala paling } \\
\text { saya ke Toilet Sebentar }\end{array}$ \\
\hline III & Bandung & Tidak & Pangen liat channel lain sembari menunggu \\
\hline IV & Makassar & Tidak & Ngapain liat, ikutan juga nggak \\
\hline V & Banjarmasin & Ya & Ya, paling pas iklan sambil sambil liat hape \\
\hline VI & Makassar & Tidak & $\begin{array}{l}\text { Pangen liat channel lain sambil nunggu } \\
\text { sinetronnya mulai lagi }\end{array}$ \\
\hline
\end{tabular}


Dari dua pertanyaan awal, peneliti melihat bahwasannya cerita atau sinetronnya sendiri adalah hal yang paling ditunggu, maka ketika suatu brand masuk menjadi bagian dari cerita. Dalam hal ini penulis melihat bahwasannya cerita ini akan berpengaruh pada sisi otak. Dimana ada 3 sisi otak dalam diri manusia yaitu, Korteks adalah tempat manusia membuat alasan dan memecahkan masalah, Midlle Brain atau Bagian tengah berkaitan dengan emosi seseorang dan Otak kadal (lizard brain) bagian yang bereaksi tanpa berpikir. Bagian ini akan membantu seseorang membuat keputusan ketika ada bahaya (Diamond, 2013:40-41). Peneliti melihat dari pernyataan informan, bahwasannya mereka akan memindahkan channel ketika konten media tersebut fokus pada sebuah produk atau merek. Peneliti melihat kondisi ini adalah sebagai ancaman yang menggangu kesenangan mereka. Dengan kata lain, Iklan yang ditampilkan secara fokus akan dianggap sebagai penggangu kesenangan mereka sehingga otak lizard ini bekerja. Oleh karena itu, Cerita adalah cara terbaik untuk melibatkan kedua sisi otak dengan mencapur informasi dengan emosi sehingga mereka merasa tidak diiklankan oleh suatu brand atau sedang menonton iklan.

Peneliti bertanya pada ke enam informan mengenai kesadaran mereka tentang produk atau brand yang ada dijalan cerita. Keenam informan menjawab bahwa mereka sadar ada brand dan produk dan ke enam informan tidak memindahkan channel. Dari keenam informan, peneliti mendapatkan jawaban beragam sebagai berikut :

\begin{tabular}{|l|l|l|l|}
\hline Informan & Asal & $\begin{array}{l}\text { Kesadaran } \\
\text { akan Brand }\end{array}$ & Alasan tetap Menonton \\
\hline I & Banjarmasin & Sadar & $\begin{array}{l}\text { Kirain bukan iklan mas.. kirain lanjutan } \\
\text { ceritanya eh taunya lagi ngomongin produk } \\
\text { minuman chocolatos. }\end{array}$ \\
\hline II & Bandung & Sadar & $\begin{array}{l}\text { Saya kira bukan iklan, abis pas masuk pas } \\
\text { mamah nya Adam ama Pricil lagi duduk eh } \\
\text { malah ngomongin keju dari perancis, hmm } \\
\text { apalah nama produknya }\end{array}$ \\
\hline III & Bandung & Sadar & $\begin{array}{l}\text { Kirain lanjutan cerita, soalnya pas banget si } \\
\text { Kania yang lagi duduk diteras sambil nyobain } \\
\text { minuman Chocolatos, kirain lajutan cerita }\end{array}$ \\
\hline V & Makassar & Sadar & $\begin{array}{l}\text { Saya dibikin heran, awalnya Kania sedih, eh } \\
\text { taunya tiba tiba akur sama mama nya } \\
\text { taunya lagi promo Beng-Beng apah gituh yang } \\
\text { diminum itu hmm lupa aku hehehe }\end{array}$ \\
\hline VI & Banjarmasin & Sadar & $\begin{array}{l}\text { Ya, saya kira udah masuk cerita taunya lagi } \\
\text { ngomongin coklat beng-beng, pantes aja } \\
\text { awalnya lagi sedih kok tiba-tiba mamanya } \\
\text { Kania akur sama Kania nya hehehe taunya } \\
\text { iklan heheheheh }\end{array}$ \\
\hline
\end{tabular}

Peneliti melihat apabila iklan yag terfokus pada tayangnya akan menjadi stimulus negative karena telah menggangu lizard braind sedangkan ketika masuk sebagai alur cerita , maka ekspektasi awal penonton bukan pada iklan nya namun pada "what next" apa yang terjadi selanjutnya pada jalan cerita sinetron ini. Sehingga otak dalam keadaan siap menerima pesan sehingga otak dan mata bisa lebih fokus pada brand yang sedang ditayangkan. Dari jawaban informan, peneliti melihat dari kalimat "saya kira lanjut" dan kalimat sepadannya, bahwa iklan insertion ini masuk ketika habis iklan dan seolah-olah kembali ke jalan cerita 
namun mereka menyadari adanya perbedaan kondisi terakhir dari pemain sebelum masuk commercial break. Namun ketika masuk kejalan cerita dan brand masuk para informan masih menjadi captive audience dimana para informan menjadi sekumpulan orang yang menonton sinetron namun mereka tidak dapat meninggalkannya (Canbridge.org). Peneliti melihat bahwa sesuatu yang tidak dapat ditinggalkanya adalah rasa ingin tahu kelanjutan sinetron tersebut. Pada akhirnya para informan menyadari adanya iklan setelah ada perbedaan cerita ketika sebelum commercial break dan lanjutan dari insertion.

Pada tahap ini peneliti melihat adanya unsur stimulus yang ikut berproses sampai pada tahap adanya kesadaran merek pada sinetron tersebut, peneliti membuat sebuah alur seperti pada (Skema 1) sebagai berikut:

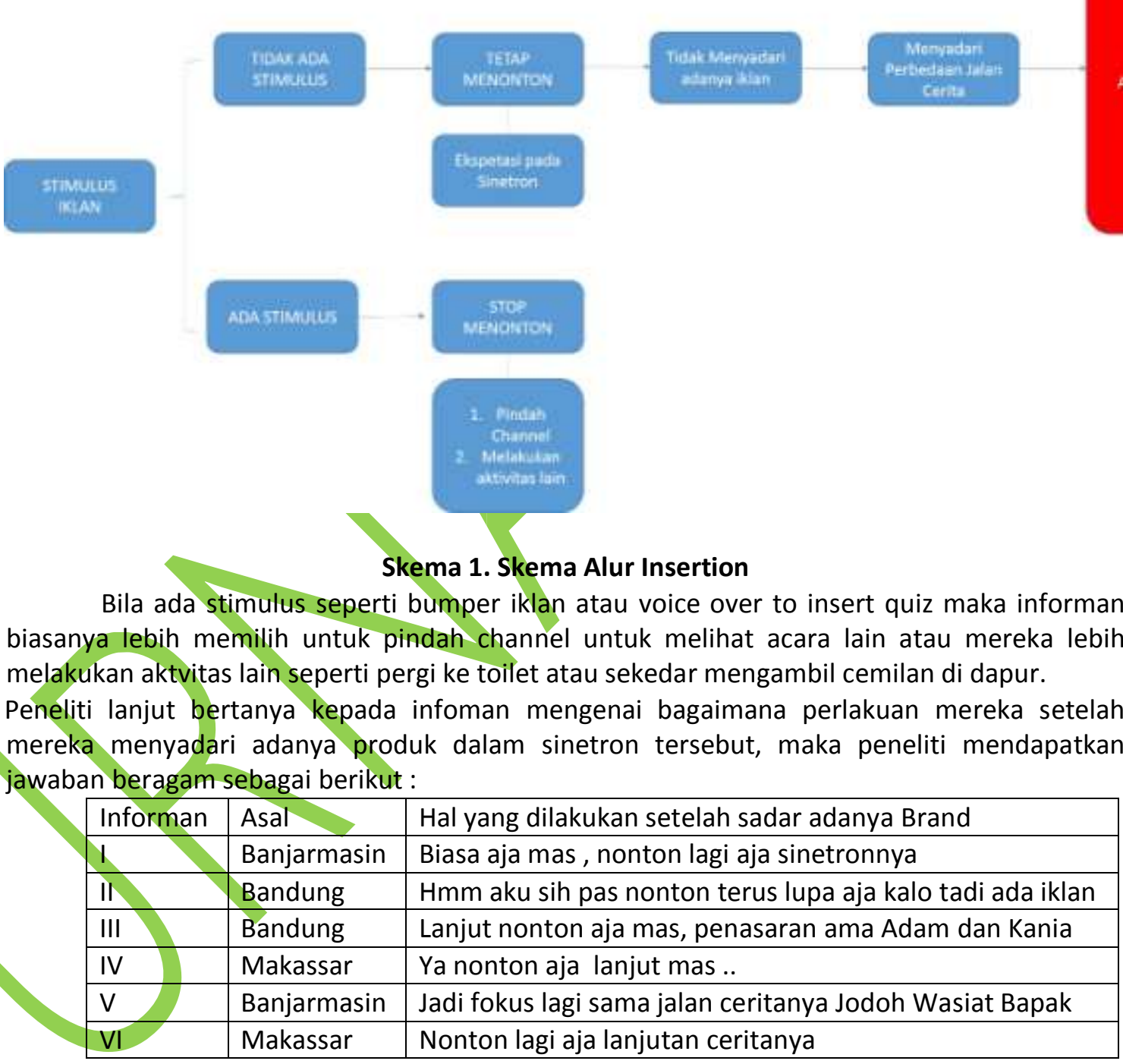

Dari jawaban informan tersebut, mereka menyadari adanya iklan namun setelah perhatian mereka kembali pada jalan ceritanya, para informan cenderung lupa dengan insertion iklan. Namun peneliti meminta mereka menyebutkan nama brand atau produk yang mereka lihat di sinetron Jodoh Wasiat Bapak dan peneliti mendapati jawaban mereka sebagai berikut:

\begin{tabular}{|l|l|l|}
\hline Informan & Asal & Nama Brand yang diingat \\
\hline I & Banjarmasin & Hmmm... Beng-Beng apa itu .. drink chocolate apa apa \\
\hline
\end{tabular}




\begin{tabular}{|l|l|l|}
\hline & & gitu \\
\hline II & Bandung & Beng-beng apa lah itu yang sekarang bisa diseduh \\
\hline III & Bandung & $\begin{array}{l}\text { Ah aku lupa nama brand nya tapi aku tau yang kejunya } \\
\text { dari perancis itu }\end{array}$ \\
\hline IV & Makassar & Chocolatos \\
\hline V & Banjarmasin & Beng-Beng drink gituh ya \\
\hline VI & Makassar & Chocolatos yang greentea \\
\hline
\end{tabular}

Dari ke enam informan didapati jawaban beragam, setelah mereka melihat brand nya maka ada saatnya informan lupa dengan jalan cerita yang mengandung iklan. Informan lanjut menonton saja. Pada saat interview, peneliti bertemu infoman bukan pada saat jam tanyang Sinetron Jodoh Wasiat Bapak, hal ini berarti ada jeda yang cukup lama ketika peneliti bertanya mengenai brand yang informan ingat ketika nonton sinetron tersebut. Ketika menjawab ada yang ingat nama brand induk nya sepeti Beng-Beng yang mengeluarkan inovasi sebagai minuman coklat seduh, namu ada yang lupa nama brand nya tapi ingat attribute nya, ada yang ingat brand namun terpisah antara nama brand dengan jenis nya seperi Chocolatos Greentea menjadi chocolatos yang greentea.

Ketika ini dijadikan sebuah skema, maka peneliti membuat alur dari kesadaran tahap pertama hingga brand ini mampu berada dalam pikiran seseorang maka peneliti membuat alurnya seperti (skema 2) berikut ini:
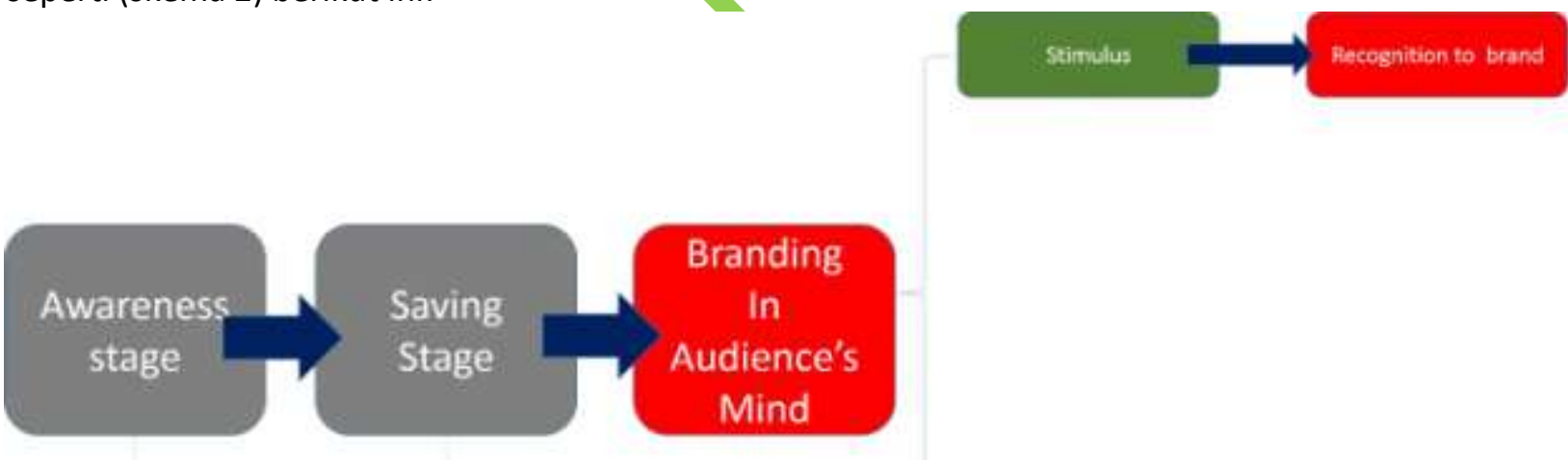

$$
\text { Shore Peniod: }
$$

\section{Skema 2. Branding in Consumer Mind}

Pada skema 2 dijelaskan bahwa ketika seseorang sudah mendapatkan awareness tentang keberadaan brand atau produk dalam sebuah alur cerita maka ia hanya bersifat short periode, dimana tidak memperdulikannya lagi. Namun hal ini tidak benar benar terlupakan, namun masuk pada saving stage dimana secara tidak sadar audience menyimpan semua pesan dalam benak mereka ( branding in audience's mind) dan ketika ada stimulus maka brand akan diingat, namun ketika mereka memiliki pengalaman dengan brand sebelumnya, maka ia akan mengingat langsung brand induknya.

Peneliti bertanya kembali kepada informan mengenai penggunaan brand-brand yang muncul di insertion sinetron Jodoh Wasiat Bapak 4 dari 6 informan mereka menggunakannya setelah datang ke mini market dan 2 diantaranya berencana menggunakan produk karena adanya pengaruh dari jalan cerita.

\begin{tabular}{|l|l|l|}
\hline Informan & Asal & Nama Brand yang diingat \\
\hline I & Banjarmasin & $\begin{array}{l}\text { Sampai saat ini belom coba mas, tapi pangen sih cobain } \\
\text { Beng Beng yang diseduh itu. Soalnya saya suka Beng- } \\
\text { Beng coklat nya, tapi nanti deh kalo nemu di warung }\end{array}$ \\
\hline
\end{tabular}




\begin{tabular}{|l|l|l|}
\hline II & Bandung & $\begin{array}{l}\text { Pas liat di warung, kok ada Beng-Beng, jadi inget Kania } \\
\text { sama Pricil di sinetron jodoh wasiat Bapak, Jadi beli deh }\end{array}$ \\
\hline III & Bandung & $\begin{array}{l}\text { Pas Liat di warung ada yang jual jadi inget pernah ada di } \\
\text { sinetron }\end{array}$ \\
\hline IV & Makassar & $\begin{array}{l}\text { Aku kalo beli ke supermarket, aku lia cholocatos ya aku } \\
\text { beli aja ,tapi saya beli waktu saya berkunjung ke rumah } \\
\text { sodara di Jakarta }\end{array}$ \\
\hline V & Banjarmasin & $\begin{array}{l}\text { Sampai saat ini belom coba sih tapi kalo ditanya gini, } \\
\text { malah jadi penasaran kayak apa sih rasa kayak yang di } \\
\text { Sinetron itu }\end{array}$ \\
\hline VI & Makassar & $\begin{array}{l}\text { Chocolatos yang greentea sih baru denger dan tahu dari } \\
\text { sinetron, saya kebetulan suka green tea , jadi pangen } \\
\text { ingin mencoba }\end{array}$ \\
\hline
\end{tabular}

Ketika Informan di stimulus oleh kegiatan komunikasi pemasaran yang lain dalam hal ini adalah packaging, maka informan ingat kembali dengan keberadaan brand pernah ada di jalan cerita Jodoh wasiat bapak. Dalam hal ini, komunikasi harus didukug dengan kegiatan komunikasi pemasaran terintegrasi lainnya seperti packaging untuk terjadinya Enggagement. Ketika seseroang melihat packaging maka ia akan kembali mengingat bahwa ia pernah melihat keberadaan produk melalui jalan cerita, hal ini berkenaan dengan struktur dalam kemasan yang bisa menunjang aktivitas komunikasi pemasaran. (Shimp, 2000). Ketersediaan produk dilapangan sangat menunjang keberhasilan sebuah branding. Peneliti membuat skema tentang proses kesadaran merek hingga mencapai enggament dari kegiatan insertion pada brand entertainment

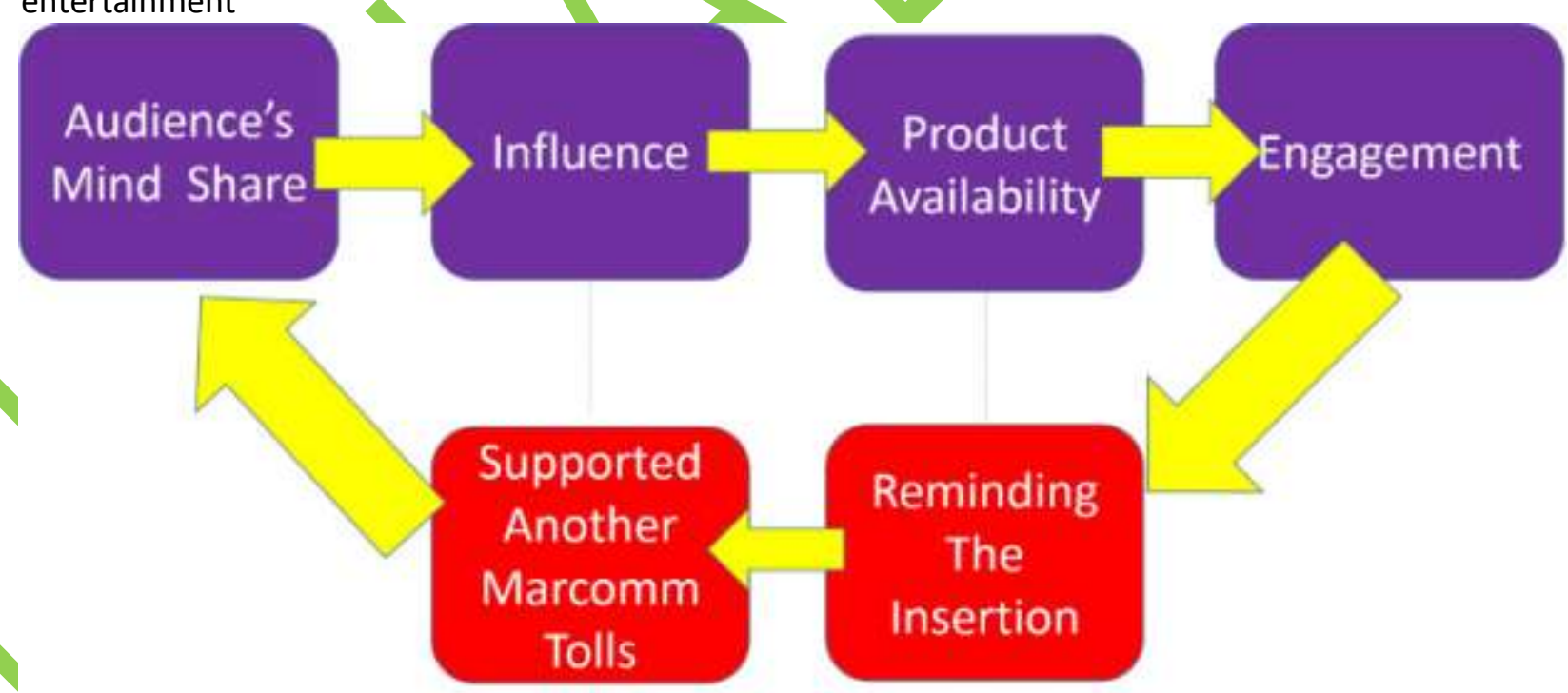

Skema 3. From Audience's Mind to Enggagement Cycle

Pada skema 3 dapat dijelaskan bahwasannya setelah suatu brand ada dalam benak seseroang melalui kegiatan insertion iklan melalui Sinetron, maka perlu andanya pengaruh dimana pengaruh tersebut merupakan terpaan dari marcomm tolls yang lain dalam penelitian ini didapati marcom tool yang dilihat oleh infoman adalah packaging dari produknya. Infoman melihat produk yang terdapat di toko, maka ketersedian produk di pasar perlu diperhatikan karena dengan adanya ketersediaan produk akan mengingatkan kembali pada product insertion. Seseorang mempunyai peluang untuk mengingat brand kembali dan melakukan Enggagement secara berulang. 


\section{SIMPULAN}

Captive audience dapat menjadi potential consumer untuk suatu brand. Pada dasarnya captive audience tidak sadar mereka sedang diinfomasikan suatu produk karena tujuan utama mereka adalah menonton sinteronnya. Dalam penelitian ini, captive audience dapat melakukan engagement produk dan mengingat bahwa ia diperkenalkan dari insertion pada sinetron tersebut.

Captive audience dapat diinformasikan iklan karena tidak ada stimulus yang jelas jelas menunjukan iklan. Namun diawali dengan espektasi mereka terhadap kelanjutan jalan cerita. Memasukan iklan dengan template sinetron misalnya dengan seolah-olah kelanjutan dari jalan cerita dengan setting yang sama seperti music scoring awal alur cerita atau dialog pemain inti akan membuat audience menjadi captive kembali dan otak mereka siap menerima dengan terbuka karena memang dalam dirinya siap untuk menerima jalan cerita sinetron bukan iklan.

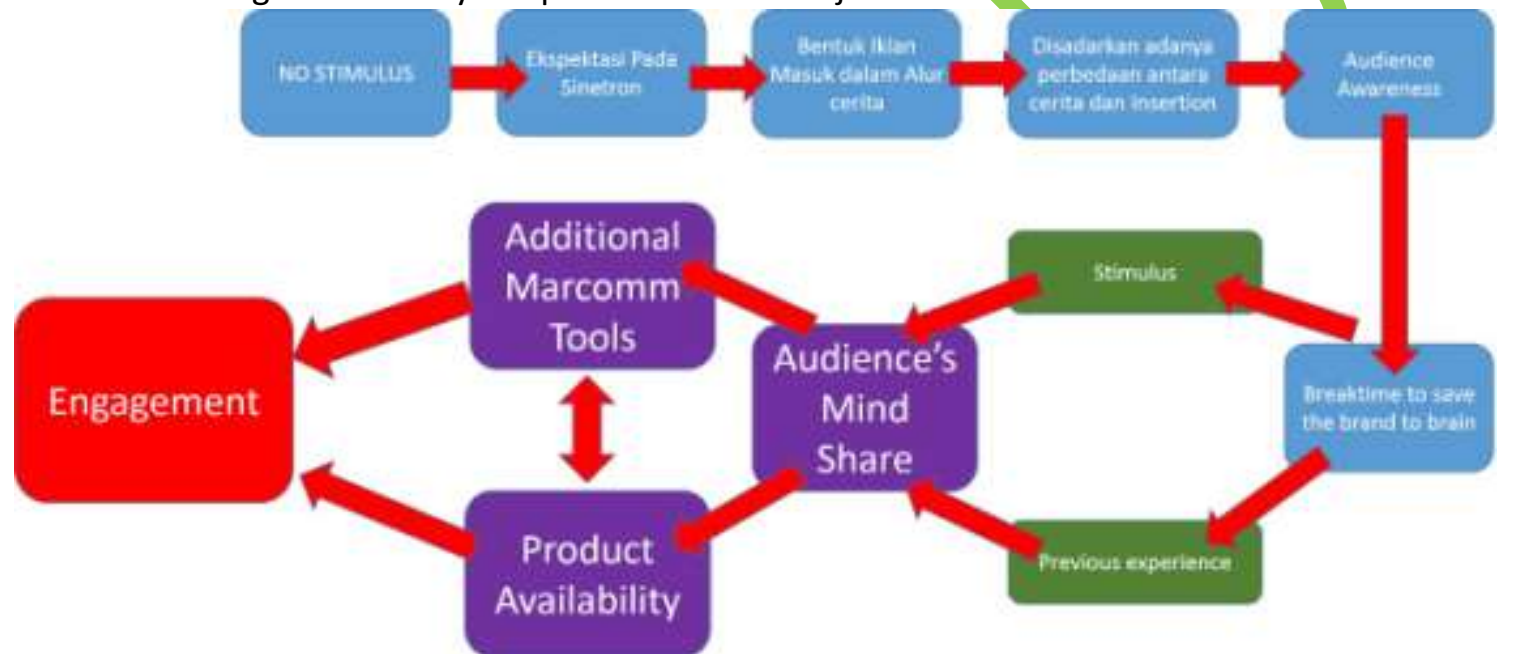

Skema 4. Alur Insertion hingga Enggagement

Dari skema 4 diatas maka brand entertainment tidak diperlukan stimulus seperti bumper atau perpindahan yang mencolok dari jalan cerita menuju iklan. Untuk itu iklan dimasukan ke alur cerita namun ritme cerita harus tetap ada perbedaan sehingga audience sadar ada keberadaan iklan. Setelah audience sadar akan keberadaan iklan, hingga tahap ini akan ada jeda, dimana jeda ini merupakan proses memasukan brand kedalam brain. Untuk waktu terteentu, audience akan mengingat kembali melalui dua cara yaitu :

1) Pertama, Stimulus, dimana audience bila ditanya oleh seseorang terkait brand yang

2) Kedua adalah pengalaman terdahulu, dimana orang pernah engage dengan brand atau produknya.

Dari dua cara tersebut, brand akan muncul lagi dalam benak audience. Untuk mencapai engagement maka harus diperhatikan 2 hal yaitu :

Aditional marcomm tool: Dalam dunia markom, tool komunikasi pemasaran diupayakan tidak lebih dari satu

Product Availability: ketersediaan produk dilapangan akan membuat orang ingat terhadap brand. Terutama ketika orang melihat packaging sebagai salah satu dari tools komunikasi pemasaran.

Maka antara tools komunikasi pemasaran dan ketersediaan produk harus saling melengkapi namun secara terpisah , masing masing bisa mencapai engagement. 


\section{DAFTAR PUSTAKA}

Diamond, Stephanie (2013) The Visual Marketing Revolution, Penerbit Serambi, Jakarta.

Egan, J. (2015), Marketing Communications. Sage. London:

Gunawan, Iman. (2013). Metode Penelitiaan Kualitatif: Teori dan Pratilik. Jakarta: Bumi Aksara. Hermawan, A. (2012). Komunikasi Pemasaran. Malang: Erlangga.

Kriyantono, Rachmat. (2014). Teknik Praktis Riset Komunikasi. Jakarta: Prenadamedia Group.

Lehu, Jean-Marc (2009). Branded Entertainment, Product Placement and Brand Strategy in Entertainment Business, Kogan Page.

Machfoedz, M. (2010). Komunikasi Pemasaran Modern. Yogyakarta: Cakra Ilmu.

Moleong, L. J. (2006). Metodologi Penelitian Kualitatif. Bandung: PT Remaja Rosdakarya.

Pamungkas, Indra Novianto Adibayu (2016). Brandology .Deepublish. Yogyakarta.

Satori, Djam'an dan Aan Komariah, (2012). Metodologi Penelitian Kualitatif. Bandung: Alfabeta.

Sugiyono. (2009). Metode Penelitian Bisnis (Pendekatan Kuantitatif, Kualitatif, dan R\&D). Bandung: Alfabeta.

Shimp, Terrence A (2000) Periklanan dan Promosi, Aspek Tambahan pada Komunikasi Pemasaran Terpadu, Penerbit Erlangga (Jakarta)

Tahir, Muh. (2011). Pengantar Metodologi Penelitian Pendidikan. Makassar: Universitas Muhammadiyah Makassar.

\section{Sumber online}

http://trendtek.republika.co.id/berita/trendtek/internet/17/07/28/otsito335-tren-menontontv-dan-internet-bersamaan-alami-peningkatan diakses pada 5 Maret 2018 pukul 10:22 WIb.

https:/ www.tabloidbintang.com/film-tv-musik/kabar/read/20300/penonton-indonesiamenyenangi-program-televisi-penuh-drama-dan-kisah-menyayat-hati diakses 6 Maret 2018 pukul 5.59 WIB

http://www.pictame.com/media/17267919494760292675335775092 diakses 6 maret 2018 pukul 6.16. WIB

http://www.pictame.com/user/rating tv/5335775092 diakses 6 maret 2018 pukul 6.18. WIB

https://www.merdeka.com/peristiwa/ini-golongan-penonton-sinetron-paling-banyak-diindonesia.html diakses 6 maret 2018 pukul 7.35. WIB

http://www.beritasatu.com/film/317910-sinetron-masih-merajai-program-tv-lokal.html diakses 6 maret 2018 pukul 7.56. WIB

https://www.antaranews.com/berita/256900/jumlah-penonton-sinetron-bertambah diakses 6 maret 2018 pukul 8.06. WIB

https://dictionary.cambridge.org/dictionary/english/captive-audience diakses 6 maret 2018 pukul 14.39. WIB 